\title{
Kimya Öğretmenlerinin Öğretimlerinde Analoji Kullanım Durumlarının İncelenmesi ${ }^{1}$
}

\author{
DOI: 10.26466/opus.957650
}

\author{
Ayşegül Derman* - Mehmet Tufan ** \\ * Doç. Dr., Necmettin Erbakan Üniversitesi, Ahmet Keleşoğlu Eğitim Fakültesi, Konya/Türkiye \\ E-Posta: aderman1977@gmail.com \\ ORCID: $\underline{0000-0003-3856-1017}$ \\ ** Yl. Öğr., Necmettin Erbakan Üniversitesi, AKEF, Konya/Türkiye \\ E- Posta: mehmettfn@gmail.com \\ ORCID: $\underline{0000-0001-8718-5391}$
}

Öz

2018-2019 akademik yılı bahar yarıylında gerçekleştirilen nitel esash bu çalışmada kimya öğretmenlerinin analoji kullanımıyla ilgili hâlihazırdaki durumlarmın, kullandıklarn analojilerin niteliklerinin belirlenmesine ve bunlarm iyileştirilmesine odaklanild. Bu araştırma bir durum çalışmasıdır. Çalışma on iki kimya öğretmeniyle gerçekleştirildi. On iki kimya öğretmeninin hâlihazırdaki analoji kullanım durumlar ve kullandıkları analojilerin nitelikleri belirlendikten sonra eğitime katılmayı kabul eden dört kimya öğretmenine analoji eğitimi verilerek eğitim sonrası öğretmenlerin kimya öğretiminde analoji kullanımı ile ilgili yeterliklerinin geliştirilmesi amaçlandı. Bu araştırmanın veri kaynağın analoji eğitimi öncesi ve sonrası kimya öğretmenlerinin açı uçlu sorulara verdikleri yazll cevaplar oluşturdu.Bu araştırmada verileri analiz etmek için içerik analizi tekniği kullanıldı. Bu araştırmada kimya öğretmenlerinin "Analojiyi" nasil anlamlandirdikları, "Derslerinde analoji kullanmm siklkları", "Derslerinde kullanacaklarn analojileri belirlerken dikkat ettikleri hususlar", "Derslerinde analojileri kullanım amaçları", "Kullandıklar analojiler için başvurdukları kaynaklar", "Derslerinde öğrencilerin analoji üretmelerine imkân tanıma durumlarn" şeklinde belirlenen kategorilere ait bulgular elde edildi. Ayrıca analoji eğitimine katılan kimya öğretmenlerinin pedagojik analojik modellerin yapısı, özellikleri, öğretimde nasıl kullanılacağı, öğretimde analoji kullanırken dikkat edilmesi gereken hususlar ile ilgili bilgi ve görüşlerinde büyük oranda gelişmeler olduğunu gösteren bulgulara ulaşıldı. Bulgular ilgili çalışmalarla karşllaştırlarak, detaylı olarak tartışld ve kimya öğretiminde analojilerin kullanımına yönelik çıkarımlarda bulunuldu. Bulgulara dayalı olarak kimya öğretmenlerine ve kimya eğitimi araştırmactlarna öneriler sunuldu.

Anahtar Kelimeler: $\quad$ Pedagojik Analojik Model, Analoji, Kimya Öğretimi, Analoji ile Öğretim Modeli.

\footnotetext{
${ }^{1}$ Bu çalışma "Kimya Ders Kitaplarindaki ve Kimya Öğretmenlerinin Gelişstirdikleri Analojilerin Incelenmesi" başlıklı yüksek lisans tezinden üretilmiştir.
} 


\title{
Examination of the Use of Analogy in the Teaching of Chemistry Teachers
}

\begin{abstract}
The present qualitative study, which was carried out in the spring semester of the 2018-2019 academic year, focused on determining the current candition of chemistry teachers regarding the use of analogies, the qualities of the analogies they use and improving them. This research is a case study. The study was carried out with twelve chemistry teachers. After determining the current use of analogies of twelve chemistry teachers, four chemistry teachers who agreed to participate in the training were given analogy training, and it was aimed to improve the competencies of the teachers about the use of analogies in chemistry teaching after training. The data source of the study was the written answers given by the chemistry teachers to open-ended questions before and after analogy training. Content analysis technique was used to analyze the data in this study. In the present research we reached the findings in the following categories; how chemistry teachers make sense of "Analogies", "frequency of use of analogies in their lessons", "the points they pay attention to when determining the analogies to be used in their lessons", "the purpose of using analogies in their lessons", "the resources they refer to for the analogies they use", "the situation of allowing students to produce analogies in their lessons". The findings also revealed that the chemistry teachers who participated in the analogy training had a great deal of improvement in their knowledge and opinions about the structure of pedagogical analogous models, their properties, how to use them in teaching, and the points to be considered when using analogies in teaching. Findings discussed in detail by comparing related studies. Based on the findings, recommendations were made for chemistry teachers and chemistry education researchers.
\end{abstract}

Key Words: $\quad$ Analogy, Pedagogical Analogy Model, Chemistry Teaching, Teaching with Analogies Model. 


\section{Giriş}

Maddenin yapısını anlama ile uğraşan kimya biliminin gelişim süreci diğer temel bilimlerde olduğu gibi zamanla öğrenilen bilgilerin kullanılabilir olması için gelecek nesillere öğretilmesi ihtiyacını doğurmuştur. Bu ihtiyaç başlangıçta usta-çırak ilişkisiyle giderilebilirken daha sonraki zamanlarda sanayi devrimiyle birlikte hızlı bir şekilde artan yetişmiş insan gücü ihtiyacı kimyanın profesyonelce, etkili ve verimli bir biçimde öğretimini gündeme getirmiştir. Kimyanın profesyonel bir kariyer alanı olarak kabul edilmesiyle birlikte öğretilmesi gereken kimya içeriğinde bir standardizasyon ihtiyacı gündeme gelmiştir. Bu ihtiyaç öğretim programlarıyla çözülmüştür (Ayas ve Sözbilir, 2017, s. 2).

Günümüz ortaöğretim kimya programı (MEB, 2018), Türk Millî Eğitiminin ana amaçları çerçevesinde, bireysel ve toplumsal sorumluluklarının bilincinde, kendi hayatını etkileyen kimyasal kavram ve ilkelerin farkında bireyler yetiştirmeyi hedeflemiştir. Öğretim programında kimyanın günlük hayatla ilişkilendirilerek öğretimi baskın bir biçimde vurgulanmaktadır. Kimya bilimi hayatın içinde çok yoğun olmasına rağmen öğrenciler kimya kavramlarını öğrenmekte zorlanmaktadır. Bu durum kimya bilgisinin, kavramlarının soyut olmasından ve epistemolojik zorluklar taşıyan yapısından kaynaklanmakla birlikte pedagojik engellerle de ilgilidir (Taber, 2008). Kimya konularını günlük hayatla ilişkilendirerek öğretmek için değişik öğretim stratejileri, metaforlar, analojiler ve modeller gibi farklı araçlar söz konusudur. Modeller kimya öğretiminde temel araçlardır. Kimya derslerinde, kimya konularının bazı yönlerini açılamak için bir veya daha fazla analojik model kullanılır. Öğretmenler en karmaşık ve soyut fen kavramlarını açılamak ve öğrencileri için daha anlaşılır kılmak için modeller kullanırlar (Harrison ve Treagust, 2000). Metaforlar, analojiler, modeller öğrencilerin soyut ve zor kavramları doğru anlamalarına yardımcıdır. Temelde öğrencilerin bilgi yapılarını kurmak ve incelemek için çok şey yapmak mümkündür. Ancak ontolojik bilgi, kişisel düzeyde kişisel bir deneyim ile ilgilidir (Harrison ve Treagust, 2000).

Bu çalışmada kimya öğretmenlerinin hâlihazırdaki analoji kullanım durumlarına, geliştirdikleri analojilerin niteliklerine ve bunların iyileştirilmesine odaklanıldı. 


\section{Araştırmanın Amacı}

$\mathrm{Bu}$ araştırmada kimya öğretmenlerinin hâlihazırdaki analoji kullanım durumlarının ve geliştirdikleri analojilerin niteliklerinin belirlenmesi ve verilen analoji eğitimi sonrası öğretmenlerin kimya öğretiminde analoji kullanımı ile ilgili görüşlerindeki ve ürettikleri analojilerin niteliklerindeki gelişme ve iyileşmelerin belirlenmesi amaçlandı.

$\mathrm{Bu}$ amaç doğrultusunda, bu araştırmada aşağıdaki sorulara cevap arand1:

- Kimya öğretmenlerinin öğretimlerinde analoji kullanımıyla ilgili hâlihazırdaki durumları ve geliştirdikleri analojilerinin nitelikleri nasildir?

- Analoji eğitimi sonrası kimya öğretmenlerinin öğretimlerinde analoji kullanımıyla ilgili görüşleri ve geliştirdikleri analojilerin nitelikleri nasıldır?

\section{Kavramsal Çerçeve}

Karmaşık görünen olayların insanlar tarafından anlaşılmasını kolaylaştırmak amacıyla kullanılan bilimsel ve zihinsel etkinliklere, model denir. Model kullanımıyla karmaşık ve soyut olgular, öğrenci tarafından daha kolay yapılandırılarak, somutlaştırılıyor ve akılda kalıcı hale getirilebiliyor (Saka, 2004, s.245). Modelleme soyut kavramların veya atom gibi gözlenemeyen varlıkların öğretilmesinde kullanılan etkili stratejilerden biri olarak tanımlanmaktadır. Modeller öğrencilerin öğrenmekte zorlandıkları kavramları anlamlandırmalarına yardımcı olurlar (Moğol, Bağ1 ve Günçiçek, 2003, s.159).

Pedagojik analojik modeller, öğretimde yaygın olarak oluşturulan ve kullanilan modellerden biridir.

Moğol ve arkadaşlarına (2003) göre; benzeşim (analoji) modelleri, modellerin ve modelleme işleminin temelini oluşturur. Model kullanarak öğrenmesi ya da öğretilmesi zor olan olgular uygun benzetmeler kullanılarak anlaşılır hale getirilir. Analoji kullanımının en önemli amacı, somut olarak bahsedilenden soyut olayları (olguları) anlamayı geliştirmektir. 
Fen eğitiminde öğrenmeyi kolaylaştıran ve anlamlı hale getiren yöntemlerden biri olan analoji (benzeşim), bilinen kavramlar ile bilinmeyen kavramlar arasında bağ oluşturmaktır (Çimen ve Baran 2000). Öğretmenler, analojileri anlaşılması zor kavramları kolaylaştırmak veya az bilinen sistemleri, olguları ve nesneleri kapsayan soyut kavramları bilinen kavramlar vasitasıyla somutlaştırmak için kullanırlar (Dagher, 2005). Analojiler, fen alanında öğrenme öğretme sürecinde en önemli unsurlardan biri olarak görülmektedir (Duit, 1991).

Duit, analoji kullanımını, kaynak bilgiden yeni bilgiye geçerken nesneler arasındaki ilişkilerin bilişsel olarak resmedilmesi olarak tanımlamıştır (Duit, 1991). Buna örnek olarak "atomun yapısının "güneş sistemine benzerliğini vermektedir.

Damarer (2006) Fizik, Kimya ve Biyoloji öğretmenlerinin derslerinde analoji tekniği kullanma sıklıkları ve kullandıkları analojilerin analizi hakkında araştırma yapmıştır. Çalışma neticesinde öğretmenlerin analoji kullanırken öğrencilerin sınıf seviyelerine dikkat ettiği, analojilerin konu içinde sunulduğu zamana ve öğrencilerin önceki bilgilerine dikkat edildiği sonucuna varmıştır.

Araştırmacılar fen derslerinde analoji kullanılabilirliğine ilişkin öğretmen adaylarıyla gerçekleştirdikleri çalışma neticesinde analojilerin anlaşılması zor ve soyut olan fen kavramlarının anlaşılmasını kolaylaştırdığı sonucuna ulaşmışlardır (Ekici, Ekici ve Aydın, 2007).

Kahraman Gökharman (2013), maddenin yapısı ve özellikleri ünitesinde analoji kullanımının öğrenci başarısı ve tutumuna etkisini incelemiştir. Çalışma neticesinde analoji kullanımının öğrenmeye olumlu etkisi olduğunu tespit etmiştir.

Adnan (2015) 12. sinıf biyoloji ders kitaplarında kullanılan analojiler üzerine bir araştırma yapmış, kullanılan analojileri çeşit ve kapsama göre incelemiştir. Çalışma neticesinde 12. sınıf biyoloji ders kitabında analojilerin sıkça kullanıldığını belirtmiş fakat kullanılan analojilerin öğretim modellerine uygun olmaması nedeniyle kullanılan analojilerden kaynaklı kavram yanılgıları olabileceğini belirtmiştir. Oluşabilecek kavram yanılgılarının önüne geçmek için öğretmenlerin kullanacakları analojileri öğretim modellerine göre geliştirmesi gerektiğini vurgulamiştır. 
Analoji ile ilgili çalışmalarda, ders kitaplarında kullanılan analojilerin incelenmesinin öneminin yanında, öğretmenlere öğretimde analoji kullanımıyla ilgili eğitim verilmesinin (Serin Ergin, 2009, s.84) ve öğretimde analoji kullanımının avantaj ve dezavantajlarından bahsedilmesinin (Damarer, 2006, s.14; Kahraman Gökharman, 2013, s.78) önemi vurgulanmıştır.

Analojiler oluşturulurken kaynak kavram ve hedef kavram arasındaki benzerliklerin, farklılıkların, yeterli ve yetersiz durumların öğretmenin rehberliği ile ortaya koyulmasının gerekliliği (Kesercioğlu, Yılmaz, Çavaş ve Çavaş, 2004, s.38) ve analojik akıl yürütmede öğretmenin rehberliğinin son derece önemli olması (Glynn, 1989, s.189) nedenleri ile öğretmenlere ve geleceğin öğretmenleri olacak öğretmen adaylarına öğretimde analojilerle ilgili teorik ve pratik boyutta bilgi verilmesinin gerekli ve önemli olduğu vurgulanmaktadır. Ayrıca hizmet içi eğitimlerde hedef ve kaynak kavram arasındaki analojik ilişkinin, benzerlik ve farklılıkların sözlü/yazılı olarak ifade edilebileceği şekilde çalıştırılabilir nitelikte olan analojilerin hazırlanması önerilmektedir (Harman ve Çökelez, 2017, s.356). Harman ve Çökelez' e göre (2017) öğretmen, öğretmen adayı ve öğrenciler analoji oluşturma ve kullanma ile ilgili aldıkları eğitimin ardından analoji oluşturmalıdır.

İlgili çalışmaların ortaya koyduğu bulgu ve öneriler ışığında çalışmamızda kimya öğretmenlerinin analoji niteliklerini geliştirmek amacıyla verilen analoji eğitiminde kılavuz çerçeve olarak Glynn 'in (1989) aşağıda detaylarını sunduğumuz "Analojilerle Öğretim ModeliniTeaching with Analogies" benimsemeyi uygun bulduk. Bu model öğretmenlere analojilerin kullanılmasında takip etmeleri gereken basamakları açıklayan bir kılavuz olmakla birlikte oluşturacakları yeni analojilerde öğrenci ve eğiticilere rehberlik etme, öğrencilerin verilen kavramı önceki yaşantılarıyla daha detaylı eşleştirerek, yeni kavramlarla ilişkisini net olarak anlamalarına katkı sağlama potansiyeline sahiptir (Kesercioğlu vd., 2004).

Analojilerle Öğretim Modelinin aşamaları aşağıda özetlenmektedir:

Öğrenilecek hedef kavram tanıtılır. Analoji kullanılmadan önce analojinin durumuna göre öğretilecek kavramla ilgili yüzeysel veya detaylı açıklama yapılır. 
Öğrencilerin analoğu hatırlamasına yardımcı olunur. Analog öğrencilere tanitılır ve sorular sorularak öğrencilerin bu analog hakkında bilgi düzeyleri ölçülür.

Hedef kavram ve analog arasındaki benzer özellikler açığa çıkartılır. $\mathrm{Bu}$ aşamada, öğrencilerden ikinci basamakta elde edilen bilgiler doğrultusunda analoğun benzer özellikleri açıklanır.

Hedef kavram ve analog arasındaki benzerlikler ortaya çıartılır. Hedef kavramın özellikleri ortaya çıkarılarak analog ile bağlantı kurulur. $\mathrm{Bu}$ sirada benzerlikler ve farklılıklar konusunda öğrenciler ile birlikte çalışmalar yapilır.

Analojinin çalışmadığı yerler göz önünde bulundurulur. Analojinin kullanımı sırasında, öğrencilerin geliştirebilecekleri olası kavram yanılgılarına dikkat edilmesi gerekmektedir. Aynı zamanda öğretmenin, analog ve hedef kavramın birbiriyle uyuşmadığı ve ilişkinin kurulmadığı alanlarda da bilgi sahibi olması gerekmekte ve bu uyuşmazlıkları ve analojinin sınırlarının öğrencilere aktarılması gerekmektedir.

Hedef kavram konusunda sonuçlar çıkarılır. Diğer öğretme stratejilerinde olduğu gibi, öğrenmeyi kolaylaştırmak için hedef kavramın önemli yönleri sonuç olarak özetlenmelidir.

\section{Yöntem}

$\mathrm{Bu}$ araştırma, kimya öğretmenlerine analoji eğitimi verilerek eğitim öncesi ve sonrası öğretmenlerin kimya öğretiminde analoji kullanımı ile ilgili durumlarının, görüşlerinin ve geliştirecekleri analojilerin detaylı bir biçimde ele alınacak olması bakımından bir durum çalışmasıdır (case study). Bu çalışmada araştırılan durum ise lise kimya öğretiminde kullanılan analojiler ve kimya öğretmenlerinin öğretimde analoji kullanımı ile ilgili bakış açılarıdır. Durum çalışması, örnek olay çalışması olarak da bilinir. Durum çalışmaları bir ya da daha fazla olayın, ortamın, programın ya da sosyal grubun derinlemesine incelendiği yöntem olarak tanımlanmaktadır. Araştırmalarda durum çalışmaları; a) Bir olayı meydana getiren ayrıntıları tanımlamak ve görmek b) Bir olayı değerlendirmek, bir olaya ilişkin olası açıklamaları geliştirmek amaçlarıyla kullanılır (Büyüköztürk, Kılıç Çakmak, Akgün, Karadeniz ve Demirel, 2008; Creswell, 2016a). 


\section{Katılımcilar}

Bu çalışma 2018-2019 akademik yılı bahar yarıylında gerçekleştirilmiştir. Bu araştırmada nitel araştırmalarda kullanılan bir örneklem seçme türü olan amaçlı örneklem kullanıldı. Bu araştırmacının bireyleri ve mekânları çalışmaya uygun olarak seçmesi demektir. Çünkü ancak bu kişiler çalışma probleminin ve çalışmanın merkezi fenomeninin anlaşılmasına yönelik gönüllü olarak bilgiler verebileceklerdir (Creswell, 2016b, s.56). $\mathrm{Bu}$ araştırmanın doğasıyla (amacı, içeriği, yapısı) ve verilecek analoji eğitimiyle (eğitimci içeriği, zamanlama gibi) ilgili olarak hâlihazırda Milli Eğitim Bakanlığına bağlı devlet okullarında çalışmakta olan on beş kimya öğretmenine sosyal medya (whatsApp) aracilığı ile bilgilendirme metni ulaştırıldı (Bakınız Ek-5). On iki kimya öğretmeni çalışmaya katılmayı kabul etti. Bunlardan sekizi analoji eğitimine katılmayı kabul etmeyip gönüllü olarak sadece eğitim öncesi soruları cevaplamayı kabul ettiler. Bu özellikteki katılımcılardan elde edeceğimiz verilerin, lise kimya öğretmenlerinin analoji ve öğretim, kimya öğretiminde analoji kullanımı konularıyla ilgili hâlihazırdaki görüşlerini, durumlarını daha detaylı kavramamıza katkı sağlayacağını düşündüğümüz için bu özellikteki katılımcıları da bu çalışmanın kapsamına almayı uygun bulduk. Bu özellikteki katılımcılar, bu çalışmada EK koduyla, numaralandırılarak sunuldu. Ancak on iki kimya öğretmeninden dört tanesi ise bu araştırmanın analoji eğitimi sürecine katılmayı gönüllü olarak kabul ettiler. Bu özellikteki katılımcılar ise bu çalışmada, K koduyla, numaralandırılarak sunuldu. Nitel araştırmada veri toplama sürecinde örneklemin büyüklüğü sorunu örneklem seçme stratejisine eşit derecede önemli bir karardır. Creswell (2016b, s.157) durum çalışmasında bir araştırma içerisinde 4 veya 5 durumdan daha fazlasının olmamasını önermektedir ve bu sayının ele alınan durumlarda temaların tanımlanması için yeterli ve geniş sayıda fırsat sağlayacağını belirtmektedir. Çalışmaya katılan kimya öğretmenleriyle ilgili demografik özellikler aşağıda Tablo 1'de sunuldu. Katılımcıların yaş ortalamaları 43.58 iken mesleki kıdem ortalamaları 21 yıldır. Analoji eğitimine katılan K1, K2, K3 kodlu katılımcılar lisans eğitimlerini eğitim fakültesi kimya öğretmenliği programında tamamlamışlar; K4 kodlu katılımcı ise lisans eğitimini fen fakültesi kimya programında tamamlamıştır. 
Tablo 1. Katılımcıların demografik özellikleri

\begin{tabular}{lllll}
\hline Katılımcılar & Cinsiyet & Yaş & Mesleki Kıdem (Yıl) & Tezli Yüksek Lisans \\
\hline K1 & Kadın & 37 & 14 & Organik Kimya \\
K2 & Kadın & 38 & 17 & Organik Kimya \\
K3 & Kadın & 38 & 17 & Kimya Ĕ̈itimi \\
K4 & Kadın & 30 & 7 & Biyokimya (Devam ediyor) \\
EK1 & Kadın & 36 & 13 & Yok \\
EK2 & Kadın & 40 & 19 & Kimya eğitimi \\
EK3 & Erkek & 44 & 23 & Yok \\
EK4 & Erkek & 54 & 32 & Yok \\
EK5 & Erkek & 60 & 30 & Yok \\
EK6 & Kadın & 48 & 28 & Yok \\
EK7 & Kadın & 48 & 25 & Yok \\
EK8 & Erkek & 50 & 27 & Yok \\
\hline
\end{tabular}

\section{Veri Toplama ve İşlem Basamakları}

$\mathrm{Bu}$ çalışmada verilecek analoji eğitimine katılmayı kabul eden dört kimya öğretmeni ile eğitim öncesi soruları cevaplamaları için görüşme günü ayarlandı. Analoji eğitimine katılmayıp sadece soruları cevaplamayı kabul eden sekiz kimya öğretmenine ise yapılandırılmış soru formu ikinci araştırmacı tarafından okullarına ulaştırılarak soruları cevaplamaları sağlandı. Tüm katılımcılara konu ile ilgili hâlihazırdaki görüşlerinin gerçekçi olarak tespit edilebilmesi için soruları cevaplamadan önce analojiyle ilgili herhangi bir araştırma, okuma yapmamaları gerektiği vurgulandı. Katılımcılardan, bu çalışmanın araştırmacıları tarafından hazırlanmış olan aşağıda Tablo 2A sütununda sunulan soruları cevaplamaları istendi. Katılımcıların soruları cevaplamaları yaklaşık 35-40 dakika sürdü. Tüm katılımcıların soruları cevaplamaları yaklaşık iki hafta sürdü. Soruların cevaplanması tamamlandıktan 1 hafta sonrasına katılımcılarla birlikte eğitim günü kararlaştırıldı. Eğitime kadar olan bir haftalık süre zarfında katılımcıların verdiği cevaplar kabaca analiz edildi, elde edilen veriler de göz önünde bulundurularak kimya öğretmenlerine verilecek analoji eğitimiyle ilgili hazırlıklar tamamlandı. İki araştırmacının da katılımıyla, birinci araştırmacı tarafından aşağıda Tablo 2B'de sunulan aşamaları içeren eğitim gerçekleştirildi. Eğitim sonrasında dört kimya öğretmeninden aşağıda Tablo $2 \mathrm{C}^{\prime}$ de sunulan soruları cevaplamaları istendi. 
Tablo 2. Analoji Ĕğitimi İşlem Basamakları

\begin{tabular}{|c|c|}
\hline Analoji eğitimi öncesi sorular & Analoji eğitimi \\
\hline $\begin{array}{l}\text { 1-Sizce analoji nedir? } \\
\text { Analojiden ne anladığınızı } \\
\text { lütfen detaylı olarak açılar } \\
\text { mısınız? }\end{array}$ & $\begin{array}{l}\text { 1-Kimya öğretmenlerine bu } \\
\text { tezin danışmanı ve araştır- } \\
\text { macısıly birlikte analoji } \\
\text { eğitimi verildi. }\end{array}$ \\
\hline $\begin{array}{l}\text { 2-Derslerinizde analoji } \\
\text { kullanıyor musunuz? Kullana- } \\
\text { cağınız analojiyi nasıl belirli- } \\
\text { yorsunuz, hangi } \\
\text { kaynağa/kaynaklara } \\
\text { başvuruyorsunuz? Lütfen } \\
\text { detaylı olarak açıklar mısınız? }\end{array}$ & $\begin{array}{l}\text { 2-Bu eğitimde kimya öğret- } \\
\text { menlerinin analoji eğitimi } \\
\text { öncesi sorulara verdikleri } \\
\text { cevaplar da göz önünde } \\
\text { bulundurularak, Prezi } \\
\text { sunum programıyla hazır- } \\
\text { lanan sunum ve etkinlik } \\
\text { çalışma yaprakları } \\
\text { kullanıldı. }\end{array}$ \\
\hline
\end{tabular}

Analoji eğitimi sonrası sorular

1-Sizce analoji nedir? Analojiden ne anladığınız lütfen detaylı olarak açıklar 2-Derslerinizde analoji kullanıldı.

\begin{tabular}{|c|c|c|}
\hline $\begin{array}{l}\text { 3-Derslerinizde analojiyi hangi } \\
\text { amaçla/amaçlarla, nasıl } \\
\text { kullanıyorsunuz? Lütfen } \\
\text { detaylı olarak açıklar mısınız? }\end{array}$ & $\begin{array}{l}\text { 3-Sunumun içeriğinde } \\
\text { "Analoji nedir? Öğretimde } \\
\text { ne amaçla kullanılır? } \\
\text { Öğretimde analoji } \\
\text { kullanımının avantaj ve } \\
\text { dezavantajları nelerdir? } \\
\text { Kimya öğretiminde } \\
\text { analojiler etkin bir biçimde } \\
\text { nasıl kullanılır? Analojilerin } \\
\text { öğretimde kullanımına } \\
\text { yönelik modeller } \\
\text { hangileridir? 1-Analoji ile } \\
\text { genel öğretim modeli 2- } \\
\text { Analoji ile öğretim modeli" } \\
\text { hususlarına yer verildi. }\end{array}$ & $\begin{array}{l}\text { 3- Lise müfredatında yer alan istediğiniz her- } \\
\text { hangi bir kimya konusuy- } \\
\text { la/olgusuyla/kavramıla ilgili bir analoji üretiniz. } \\
\text { Lütfen bu analojiyi hangi kriterleri göz önünde } \\
\text { bulundurarak, nasıl ürettiğinizi tüm yönleriyle, } \\
\text { detaylı olarak açıklayınız? }\end{array}$ \\
\hline $\begin{array}{l}\text { 4-Lise müfredatında yer alan } \\
\text { istediğiniz herhangi bir kimya } \\
\text { konusuyla / kavramıyla / } \\
\text { olgusuyla ilgili bir analoji } \\
\text { üretiniz. Lütfen bu analojiyi } \\
\text { hangi kriterleri göz önünde } \\
\text { bulundurarak, nasıl ürettiğinizi } \\
\text { tüm yönleriyle, detaylı olarak } \\
\text { açıllayınız? }\end{array}$ & $\begin{array}{l}\text { 4- Analoji ile öğretim } \\
\text { modeline odaklanıldı. Bu } \\
\text { modelle ilgili dört farklı } \\
\text { etkinlik (Azizoğlu, Aslan ve } \\
\text { Pekcan, 2015, s.472-488) } \\
\text { üzerinde çalışıldı, tartışıldı. }\end{array}$ & $\begin{array}{l}\text { 4- Ürettiğiniz bu analojiyi derste hangi amaçla, } \\
\text { nasıl kullanabilirsiniz? Lütfen detaylı olarak } \\
\text { açıklayınız. }\end{array}$ \\
\hline $\begin{array}{l}\text { 5- Ürettiğiniz bu analojiyi } \\
\text { derste hangi amaçla, nasıl } \\
\text { kullanırsınız" Lütfen detaylı } \\
\text { olarak açılar mısınız? } \\
\end{array}$ & $\begin{array}{l}\text { 5-Kimya öğretmenlerinden } \\
\text { "Analoji ile öğretim ko- } \\
\text { nusunda daha önce sahip } \\
\text { olduğunuz bilgiler, şu an } \\
\text { sahip olduklarınızdan nasıl } \\
\text { farklılaşmaktadır" } 1 \text { ortaya } \\
\text { koyan bir yansıtma günlüğü } \\
\text { yazmaları istendi. }\end{array}$ & $\begin{array}{l}\text { 5- Bundan sonraki süreçte derslerinizde öğren- } \\
\text { cilerinizin analoji üretmelerine imkân tanıyacak } \\
\text { mısınız? Cevabınız evet ise bunu ne amaçla } \\
\text { yapacağınızı ve bu işlemi nasıl } \\
\text { gerçekleştireceğinizi lütfen detaylı olarak } \\
\text { açıklayınız. Cevabınız hayır ise sebebini lütfen } \\
\text { i detaylı olarak açıklayınız. }\end{array}$ \\
\hline $\begin{array}{l}\text { 6-Derslerinizde öğrencil- } \\
\text { erinizin analoji üretmelerine } \\
\text { imkân tanıyor musunuz? } \\
\text { Cevabınız evet ise bunu niçin }\end{array}$ & & $\begin{array}{l}\text { 6- Bu eğitimin size katkı sağladığını düşünüyor } \\
\text { musunuz? Gerçekleştirdiğimiz bu analoji eğitimi } \\
\text { sürecinde edindiğiniz bilgi ve becerileri mes- } \\
\text { lektaşlarınızla paylaşmayı düşünüyor musunuz? }\end{array}$ \\
\hline
\end{tabular}

2- Bundan sonraki süreçte derslerinizde analoji kullanırken neleri, hangi kriterleri göz önünde bulunduracaksınız? Derslerinizde analojiyi hangi amaçlarla, nasıl kullanacaksınız? Lütfen detaylı olarak açıklar mısınız? becerileri derslerinize/öğretiminize entegre etmeyi düşünüyor musunuz? Açıklayınız. 
yaptığınızı ve bu işlemi nasıl gerçekleştirdiğinizi lütfen detaylı olarak açılayınız. Cevabınız hayır ise sebebini lütfen detaylı olarak

açıklayınız
Açılayınız. Bu eğitimle ilgili düşünce, görüş ve önerilerinizi lütfen bizimle paylaşır mısınız?

Analoji eğitimi öncesi ve sonrası kimya öğretmenlerinin yukarıda Tablo 2A ve C'de sunulan sorulara yazılı olarak verdikleri cevaplar bu araştırmanın veri kaynağını oluşturdu.

\section{Veri Analizi}

Bu çalışmada verileri analiz etmek için içerik analizi (Berg ve Lune, 2015, s.380) tekniği kullanıldı. Kalıpları, temaları, önyargıları ve anlamları tespit etmek amacıyla belirli bir materyalin dikkatlice, ayrıntılı ve sistematik olarak incelenmesi ve yorumlanmasına içerik analizi denilir. Analiz içeriği araştırma soruları ile ilişkilendirilecek bir veri olarak kodlama için tasarlanmıştır (Berg ve Lune, 2015, s.380). Kodlamayla ilgili hususlar ise; araştırmacının a) sadece katılımclardan toplanan bilgiyi temel alarak kodları geliştirmesi b) önceden belirlenmiş kodları kullanması, sonra verileri bu kodlara uygun hale getirmesi veya c) ortaya çıkan ve önceden belirlenmiş kodların bir kombinasyonunu kullanmasıdır (Creswell, 2016a, s.199). Bu çalışmada kimya öğretmenlerinin analoji eğitimi öncesi ve sonrası açık uçlu sorulara yazılı olarak verdikleri cevapların analizinde ise yukarıda kodlamayla ilgili hususlarda "a" seçeneğinde yapılan açıklamayla uyumlu olarak kimya öğretmenlerinin verdikleri cevaplar/bilgiler doğrultusunda kodlar geliştirildi (bakınız Tablo 4 ve Tablo 5). Ayrıca, kimya öğretmenlerinin görüşlerini detaylandırmak için kimya öğretmenlerinin verdikleri cevaplardan (katılımcı kodu belirtilerek, K1, K2 gibi), doğrudan alıntılara yer verildi.

Yukarıda kodlamayla ilgili hususlarda " $b$ " seçeneğinde yapılan açıklamayla uyumlu olarak bu çalışmada kimya öğretmenlerinin analoji eğitimi öncesi ve sonrası geliştirdikleri analojilerin (bakınız Tablo 6) analizinde analojilerin sınıflandırılmasıyla ilgili olarak alan yazında ortaya konulan kriterlerden (Cha, Byun ve Noh, 2004; Harman ve Çökelez, 
2017; Thiele ve Treagust, 1995, s.783) yararlanılarak araştırmacılar tarafından oluşturulan kategorik çerçeve (bakınız Tablo 3) kullanıldı. Analizin güvenirliğini sağlamak için katılımcıların geliştirdiği analojilerin analizinde \%100 görüş birliği sağlanana kadar araştırmac1 analoji analizlerini danışmanıyla (uzman desteği) birlikte gerçekleştirdi. \%100 görüş birliği sağlandıktan sonra araştırmacı analizleri bireysel olarak tamamladi.

Tablo 3. Analojilerin analizinde kullanılan kategorik çerçeve (Cha, Byun ve Noh, 2004; Harman ve Çökelez, 2017; Thiele ve Treagust, 1995, s.783)

\begin{tabular}{|c|c|c|c|}
\hline ANALOJI & KRİTER & ANALOJININ TÜRÜ & AÇIKLAMA \\
\hline & Paylaşılan özel- & Yapisal & Şekil, boyut, renk gibi yapısal özellikler paylaşılır. \\
\hline & liklerin & İşlevsel & Rol, davranış gibi işlevsel özellikler paylaşılır. \\
\hline & doğası & Yapısal/İşlevsel & Hem yapısal hem de işlevsel özellikler paylaşılır. \\
\hline & \multirow[t]{3}{*}{ Temsil şekli } & Sözel & Kaynağın etki alanında sadece sözel içerik vardır. \\
\hline & & Görsel & Kaynağın etki alanında sadece görsel temsil vardır. \\
\hline & & Sözel / Görsel & $\begin{array}{l}\text { Kaynağın etki alanında hem görsel hem de sözel } \\
\text { içerik vardır. }\end{array}$ \\
\hline & \multirow[t]{3}{*}{ Soyutlama } & Somut - Somut & Hem kaynak hem de hedef somuttur. \\
\hline & & Soyut - Soyut & Hem kaynak hem de hedef soyuttur. \\
\hline & & Somut - Soyut & Hedef soyut, kaynak somuttur. \\
\hline & \multirow[t]{3}{*}{$\begin{array}{l}\text { Eşleştirme de- } \\
\text { recesi }\end{array}$} & Basit & $\begin{array}{l}\text { Açılama yapılmadan sadece hedef ve kaynak } \\
\text { arasındaki benzerlikler ifade edilir. }\end{array}$ \\
\hline & & Zenginleştirilmiş & Paylaşılan özelliklerin bazılarını gösterir. \\
\hline & & Genişletilmiş & $\begin{array}{l}\text { Hedefi açıklamak için kaynağın birçok özelliğini ya } \\
\text { da birçok kaynağı içerir. }\end{array}$ \\
\hline & \multirow[t]{2}{*}{ Yapaylık } & Günlük içerik & $\begin{array}{l}\text { Günlük nesneler ya da olaylar değiştirilmeden } \\
\text { kullanılır. }\end{array}$ \\
\hline & & Yapay içerik & $\begin{array}{l}\text { Günlük nesneler ya da olaylar bazı değişiklikler } \\
\text { yapılarak kullanılır. }\end{array}$ \\
\hline & \multirow{2}{*}{$\begin{array}{l}\text { Analoji teriminin } \\
\text { kullanımı }\end{array}$} & Kullanılan & Analoji ya da analojik terimini içerir. \\
\hline & & Kullanilmayan & Analoji ya da analojik terimini içermez. \\
\hline & \multirow[t]{2}{*}{ Sistematik olarak } & Yüksek & Kaynak ile hedef arasındaki nedensel ilişkileri içerir. \\
\hline & & Düşük & $\begin{array}{l}\text { Kaynak ile hedef arasındaki nedensel ilişkileri } \\
\text { içermez. }\end{array}$ \\
\hline & \multirow{2}{*}{$\begin{array}{l}\text { Sinırlılıkların } \\
\text { tanımlanması }\end{array}$} & Tanımlanmış & Paylaşılmayan özellikler açıklanır. \\
\hline & & Tanımlanmamış & $\begin{array}{l}\text { Paylaşılmayan özelliklere ait herhangi bir açılama } \\
\text { yoktur. }\end{array}$ \\
\hline & \multirow{2}{*}{$\begin{array}{l}\text { Hedef ve } \\
\text { analojinin alan- } \\
\text { larına göre }\end{array}$} & Alan içindeki analojiler & Hedef ve analoğun aynı alandan seçildiği analojiler. \\
\hline & & Alanlar arası analojiler & $\begin{array}{l}\text { Hedef ve analoğun farklı alanlardan seçildiği } \\
\text { analojiler. }\end{array}$ \\
\hline
\end{tabular}

Kimya öğretmenlerinin geliştirdikleri analojiler analiz edilirken katılımcı ve geliştirdiği analoji için kullanılan kodlamalarda (bakınız Tablo 7); K1A1: Analoji eğitimi öncesi ve sonrası sürecin tamamina katılan katılımcılardan birinci katılımcının analoji eğitimi öncesi 
geliştirdiği analoji; K1A2: Aynı katılımcının analoji eğitimi sonrası geliştirdiği analoji; EK1A: Sadece analoji eğitimi öncesi soruları cevaplayan katılımcılardan birinci katılımcının geliştirdiği analoji anlamina gelmektedir.

\section{BULGULAR}

Analoji Eğitimi Öncesi Kimya Öğretmenlerinin Öğretimlerinde Analoji Kullanımıyla İlgili Görüşlerine Dayalı Olarak Elde Edilen Bulgular.

Analoji eğitimi öncesi kimya öğretmenlerine yöneltilen açık uçlu sorulara (bakınız Tablo 2A) kimya öğretmenlerinin verdikleri cevaplar betimsel içerik analizi ile analiz edilerek kategoriler ve kodlara ulaşıldı. Bu analiz sonucunda elde edilen bulgular aşağıda Tablo 4 'te sunuldu.

Tablo 4. Kimya öğretmenlerinin öğretimlerinde analoji kullanım durumlarına ilişkin cevaplar

\begin{tabular}{|c|c|}
\hline Kategoriler & Katılımcılar (Frekans) \\
\hline \multicolumn{2}{|l|}{ A. Analoji } \\
\hline 1.Modelleme & K1,EK2, EK3 (3) \\
\hline 2.Görselleştirme & $\mathrm{K} 1(1)$ \\
\hline 3.Benzetme & $\mathrm{K} 1, \mathrm{~K} 2, \mathrm{~K} 3, \mathrm{~K} 4, \mathrm{EK} 1, \mathrm{EK} 2, \mathrm{EK} 4, \mathrm{EK} 8$ (8) \\
\hline 4. İlişkilendirme & EK1, EK5, EK6 (3) \\
\hline 5.Çağrışım & K1 (1) \\
\hline 6. Hiçbir fikrim yok & EK7 (1) \\
\hline \multicolumn{2}{|l|}{ B. Derslerinde analoji kullanma sıklıkları } \\
\hline 1.Mümkün oldukça kullanmaya çalışıyorum & $\mathrm{K} 1(1)$ \\
\hline 2.Kullaniyorum & K2, EK5, EK8 (3) \\
\hline 3.Sıkça kullanıyorum & K4 (1) \\
\hline 4.Ara sira kullaniyorum & K3, EK1,EK6 (3) \\
\hline 5.Çok az kullaniyorum & EK4 (1) \\
\hline 6.Modelleme veya benzetme kullanıyorum & EK2 (1) \\
\hline 7.Akıllı tahtadan görselleri kullanıyorum & $\operatorname{EK} 3(1)$ \\
\hline 8. Analoji ile ilgili fikrim olmadığı için kullanıp & EK7 (1) \\
\hline kullanmadığımı bilemiyorum & \\
\hline
\end{tabular}

kullanmadığımı bilemiyorum

C. Derslerinde kullanacakları analojileri belirlerken dikkat ettikleri hususlar

1.Günlük hayattan olması.

2.Öğrencilerin ilgisini çeken olgular

K1, K4, EK1, EK5 (4)

3.Kavramlar, konular, kazanımlara uygunluk

4.Öğrencilerin seviyesi, ilgi düzeyine uygunluk

K1 (1)

5. Cevap yok

EK5, EK8 (2)

$\mathrm{K} 2, \mathrm{~K} 3(2)$

D. Derslerinde analojileri kullanım amaçları

1.İlgi çekme, derse katılmalarını sağlama

EK2, EK3, EK4,EK6, EK7 (5)

2.Kalıcılığı sağlamak, Etkili öğrenmeyi sağlamak için

$\mathrm{K} 1, \mathrm{~K} 3, \mathrm{~K} 4$ (3)

3.Anlamalarını sağlamak, kolaylaştırmak için

K1, K2, K3, K4, EK1,EK5, EK6 (7)

K1, K2, K3, K4, EK1, EK2, EK3, EK4, EK6, EK8

(10) 
4.Soyut konuları somutlaştırmak için

K1, K3, EK2, EK5 (4)

5.Eski bilgilerini açığa çıkarma, yanlış bilgilerini doğruya

K4 (1)

çevirme

6. Cevap yok

EK7 (1)

\section{E. Kullandıkları analojiler için başvurdukları kaynaklar}

1.Herhangi bir kaynak belirtmeyenler

K1, K2, EK4, EK6, EK7, EK8 (6)

2.Doğaçlama olarak o anda aklıma gelen örnekler olabiliyor, K3, EK1, EK2 (3)

kendim oluşturmaya çalışıyorum

3.Daha önce okuduklarımdan aklımda kalan örnekler $\quad$ K3 (1)

olabiliyor

4.İnternet K4, EK1 (2)

5.Akıllı tahta uygulamaları K4, EK3 (2)

6.Kitap vb. bir kaynak $\quad$ EK1 (1)

7. Günlük hayat, doğa $\quad$ EK5 (1)

F. Derslerinde öğrencilerin analoji üretmelerine imkân

tanıma durumları

1. Mümkün olduğunca öğrencilerime fırsat veriyorum

2. Ara sira

$\mathrm{K} 1, \mathrm{~K} 2, \mathrm{~K} 3, \mathrm{~K} 4, \mathrm{EK} 5(5)$

3. Çalıştığım kurumlarda öğrenci seviyesi buna uygun

EK6, EK8 (2)

değildi

EK1 (1)

4. Doğaçlama gelişen durumlar dışında buna ayrı bir zaman EK2 (1) ayırmıyorum. Sınıfların kalabalık oluşu, müfredatın yoğunluğu gibi faktörler ve analoji üretme ile ilgili yeterli bilgi

sahibi olmamam bunun sebepleri arasında

5. Hayır. Zaman bulmakta zorlanıyorum. Daha çok konular-EK4 (1)

la ilgili testler çözmeyi tercih ediyorum.

6. Cevap yok

EK3, EK7 (2)

\section{Tablo 5. Analoji eğitimi sonrası kimya öğretmenlerinin öğretimde analoji} kullanımıyla ilgili görüşleri

\begin{tabular}{|c|c|}
\hline Kategoriler & Katılımcılar \\
\hline \multicolumn{2}{|l|}{$\begin{array}{l}\text { A. Analoji eğitiminde edindiği bilgi ve becerileri derslerine entegre etmeyle ilgili } \\
\text { düşünceleri }\end{array}$} \\
\hline $\begin{array}{l}\text { 1. Kesinlikle düşünüyorum. Bilmeden de zaten kullanıyormuşum. Ama sistematiğini } \\
\text { bilmediğimi fark ettim. Artık daha bilinçli bir şekilde uygulayacağım. }\end{array}$ & $\mathrm{K} 1, \mathrm{~K} 2$ \\
\hline $\begin{array}{l}\text { 2. Bu eğitimde edindiğim bilgi ve becerileri ders işlerken kullanmayı ve planlama } \\
\text { yaparken bunları dikkate almayı düşünüyorum. Öğrencilerin öğrenmekte zorlandığı }\end{array}$ & K3 \\
\hline $\begin{array}{l}\text { konu ve kavramları bu yöntemle daha kolay öğretebileceğimi düşünüyorum. } \\
\text { 3. Derslerimde kesinlikle kullanacağım. Analoji kavramını daha iyi anladığımı } \\
\text { düşünüyorum }\end{array}$ & K4 \\
\hline
\end{tabular}

B. Derslerinde analoji kullanırken göz önünde bulunduracakları hususlar

1. Öğrencilerin hazır bulunuşluklarını (kaynak) dikkate alarak onların ilgileri doğrul- $\quad \mathrm{K} 1$

tusunda günlük hayattan analoji üretmeye çalışacağım. Analoji kullanırken ben-

zerliklerin yanında farklılıkları da (analojide kaynak ve hedef arasındaki paylaşılmayan

özellikler) vurgulayarak yanlış algıların önüne geçmeye çalışacağım.

2. Kaynak (analog) belirlerken öğrencilerin ön bilgilerini, geçmiş deneyimlerini göz

önünde bulunduracağım. Analojide kaynak ve hedef arasındaki farklılıkları vurgula-

manın önemini anladım. Bu sebeple analojilerde kullandığım kaynakla hedef arasındaki

farklılıkları belirteceğim. Analojiyi konuyu (hedefi) bilindik öğelerle benzerlik ve

farklılıkları vurgulayarak kullanacağım.

3. Seçtiğim analoğun anlatacağım konu veya vereceğim kazanımla ilgili (hedef) ben-

zerliklerini ve farklı yönlerini belirleyip, bunları vurgulamaya dikkat edeceğim. Analoji 
kullanımının sonunda hedef kavramı özellikle vurgulayacağım.

4.Analoji ile öğretim modelinin aşamalarını göz önünde bulunduracağım.

$\mathrm{K} 3, \mathrm{~K} 4$

\section{Derslerinde analojileri kullanım amaçları}

1. Soyut kavramları somutlaştırmak, olguları içselleştirmek amacıyla kullanacağım.

Kavramı/olguyu öğrencilere aktarırken daha güçlü açıklamalar için kullanabilirim.

Günlük yaşamlarından seçilen analojinin dikkat çekme fonksiyonu da olur.

2. Doğrudan ölçülemeyen, belirlenemeyen, gözlenemeyen, soyut olguları açıklamak amacıyla kullanacağım.

3. Anlaşılması zor olan birçok konuda, öğrencilerin daha kolay ve iyi anlamalarını

$\mathrm{K} 1$

$\mathrm{K} 2$

K3 sağlamak amacıyla kullanabileceğimi düşünüyorum.

4. Öğrencilerin bilgiyi yanlış yapılandırmalarına sebebiyet vermemek, yanlış bilgilerini K4 doğruya çevirmek ve hedef bilgiyi en iyi şekilde oluşturmak amacıyla kullanacağım.

D. Bundan sonraki süreçte derslerinde öğrencilerin analoji üretmelerine imkân tanımayla ilgili düşünceleri

1. İmkân tanıyacağım. Öğrencilerin süreçte aktif olmalarının kalıcılığı, derse karşı ilgi ve K1 motivasyonu arttıracağını düşünüyorum.

2. Kesinlikle süre elverdiği ölçüde imkân tanıyacağım. Kimya öğretiminde en önemli sorunlardan biri de zaman kısıtlaması. Zaman zaman analoji olduğunu vurgulamadan öğrencilerden güncel örnekler istiyordum ancak artık daha sistematik şekilde uygulayacağım

3. Konuyu anlattıktan sonra, kendi rehberliğimde analoji üretmelerine firsaadnant tanıyacă̆ım.

4. Fırsat vereceğim. Öğrencilerin ürettikleri analojileri, analoji ile öğretim modelinin aşamalarına göre değerlendireceğim.

\section{E. Aldıkları Analoji eğitimiyle ilgili düşünceleri}

1. Bu eğitimde edindiğim bilgileri (branş ayırt etmeden) meslektaşlarımla paylaşmayı düşünüyorum. Daha önce analojiyi benzetim, modelleme, görselleştirme olarak düşünüyordum. Şimdiye kadar aslında farkında olmadan kullanıyormuşum. Ama önceden sadece benzerlikleri vurgulayarak kullanıyordum, artık ortak olmayan özelliklerini de vurgulayarak kavram yanılgılarının, yanlış öğrenmelerin önüne geçebilirim. 2. Diğer öğretmen arkadaşlarımla da paylaşacağım. Çok verimli bir eğitim süreci geçirdik. Bu konudaki eksiklerimi keşfettim. Daha önceki bilgilerimde sadece örnek ve benzerlik odaklı düşündüğümü fark ettim. Bu süreçte analojide analog ile hedef arasındaki farklılıkları vurgulamanın önemini daha iyi anladım.

3. Bu eğitimin bana katkı sağladığını düşünüyorum. Öğretim sırasında kullandığım (ne K3 olduğunu tam olarak bilmesem de) bir yöntemdi. Fakat örneği (kaynak) verdikten sonra konunun kazanımlarıyla (hedef) bağdaştırmakta ve öğrenciyi örneğin içinden çıkarmakta zorlanıyordum. Artık daha etkili kullanacağımı düşünüyorum.

4. Bu eğitimin bana katkı sağladığını düşünüyorum. Bütün alan dersi öğretmenlerine, K4 analojiyi daha iyi öğrenmelerini sağlamak, hatalı ve yanlış bilgilerini önlemek amacıyla bu tarz eğitim imkânları sunulmalıdır. Daha önce analojinin öğretimde kullanımıyla ilgili modellerle ilgili hiçbir bilgim yoktu. Öğrencilerde yanlış kavramaların oluşmasına sebebiyet vermiş olabileceğimi düşünüyorum. Bu eğitimde analoji ile öğretim modelini kavradığımı düşünüyorum.

Analoji eğitimi sonrası kimya öğretmenlerinin öğretimde analoji kullanımıyla ilgili görüşlerinde öne çıan hususlar Tablo 5'te detaylı olarak sunuldu.

Kimya öğretmenlerinin analoji eğitiminde edindikleri bilgi ve becerileri derslerine entegre etmeyle ilgili görüşlerinde dört katılımcının da 
olumlu görüş bildirdiği görülmektedir (Tablo 5A). Olumlu görüşlerin detaylarını sunmak için aşağıda katılımcıların görüşlerinden doğrudan alıntılara yer verildi.

"Kesinlikle evet. Bilmeden zaten kullanıyormuşum. Ama şu andan sonra daha bilinçli bir şekilde uygulayacağım." (K1)

"Kesinlikle. Analojiyi zaten kullandığımı ama sistematiğini bilmediğimi fark ettim." (K2)

"Evet. Burada öğrendiğim bilgi ve becerileri ders işlerken kullanmayı ve planlama yaparken bunları dikkate almayı düşünüyorum. Öğrencilerin öğrenmekte zorlandığı konu ve kavramları bu yöntemle daha kolay öğretebileceğimi düşünüyorum." (K3)

"Evet düşünüyorum. Analoji kavramını daha iyi anladığımı düşünüyorum. Öğrencilere vereceğim örnekleri yanlış anlamamalarını, öğrenme hatalarının olmamasına dikkat etmeyi düşünüyorum..." (K4)

Kimya öğretmenlerinin derslerinde analoji kullanırken göz önünde bulunduracakları hususlarla ilgili öne çıkan bilgiler Tablo 5B' de; derslerinde analojileri ne amaçla kullanacakları Tablo 5C'de; bundan sonraki süreçte derslerinde öğrencilerin analoji üretmelerine imkân tanımayla ilgili düşünceleri Tablo 5D'de; bu süreçte aldıkları analoji eğitimiyle ilgili düşünceleri Tablo 5E'de detaylı olarak sunuldu.

\section{Kimya Öğretmenlerinin Geliştirdikleri Analojiler}

Analoji eğitimi öncesi ve sonrası kimya öğretmenlerinin geliştirdikleri analojiler Tablo $3^{\prime}$ te sunulan kategorik çerçeveye göre analiz edildi. Elde edilen bulgular aşağıda Tablo 6' da sunuldu.

Tablo 6. Analoji eğitimi öncesi ve sonrası kimya öğretmenlerinin geliştirdikleri analojilerin analizi

\begin{tabular}{|c|c|c|c|c|c|c|c|c|c|c|c|c|c|c|c|c|c|c|c|}
\hline KRITER & ANALOJININ TÜF & $\ddot{\mathrm{U}} \underset{\underline{\Xi}}{\ddot{Z}}$ & $\underset{\mathbb{d}}{\mathbb{d}}$ & $\begin{array}{l}\text { 离 } \\
\underline{1}\end{array}$ & $\underset{7}{Z}$ & $\frac{\mathbb{3}}{\mathrm{z}}$ & 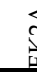 & & & & 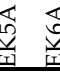 & & 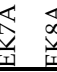 & & $\frac{\pi}{\mathbb{Z}}$ & 亲 & $\underset{\mathbb{Z}}{\mathbb{Z}}$ & 荇 & 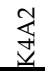 \\
\hline \multirow{4}{*}{$\begin{array}{l}\text { Paylaşılan } \\
\text { özelliklerin } \\
\text { doğası }\end{array}$} & Yapisal (2 Adet) & $X$ & & & Ö & & & - & & & Ö & - & $\mathrm{x}$ & & & & & & \\
\hline & İşlevsel (11 Adet) & & $\mathrm{X}$ & $x$ & & $\mathrm{X}$ & $\mathrm{X}$ & - & $\mathrm{X}$ & $\mathrm{X}$ & & - & & $x$ & $x$ & $x$ & $\mathrm{x}$ & $\mathrm{X}$ & $\mathrm{X}$ \\
\hline & Yapisal/İşlevsel & & & & & & & - & & & & - & & & & & & & \\
\hline & Sözel (13 Adet) & $x$ & $x$ & $x$ & & $x$ & $x$ & - & $\mathrm{X}$ & $\mathrm{X}$ & & - & $\mathrm{X}$ & $\bar{x}$ & $\bar{x}$ & $\bar{x}$ & $\bar{x}$ & $x$ & $x$ \\
\hline \multirow{2}{*}{ Temsil şekli } & Görsel & & & & & & & - & & & & - & & & & & & & \\
\hline & Sözel / Görsel & & & & & & & - & & & & - & & & & & & & \\
\hline oyutlama & Somut - Somut (1 & & $x$ & & & & & - & & & & - & & & & & & & \\
\hline
\end{tabular}




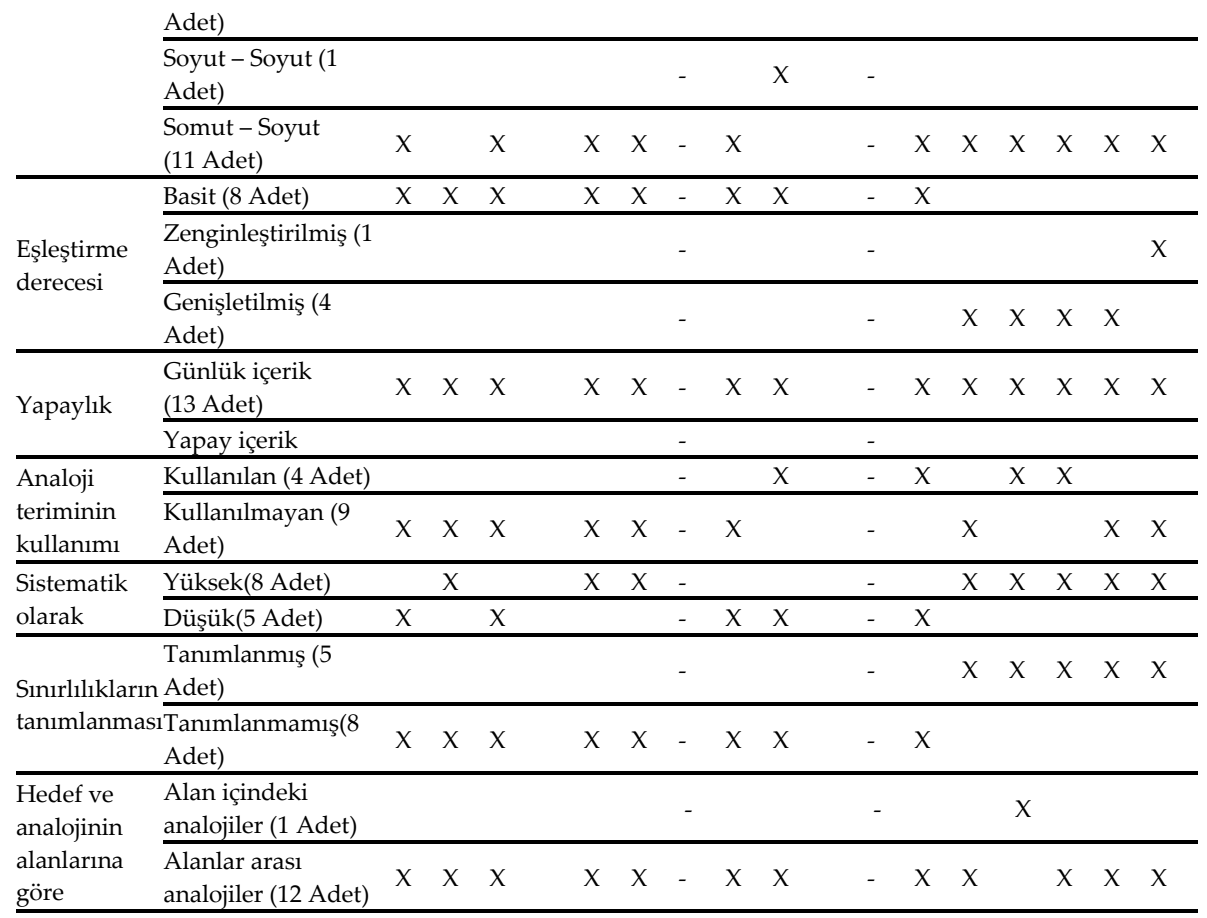

(Not: Tablodaki Ö harfi analoji geliştirmek yerine günlük hayattan verilen örnekleri ifade etmek için; - işareti ise herhangi bir analoji geliştirilmediğini ifade etmek için kullanıldı. K2 kodlu katılımcı analoji eğitimi sonrası iki analoji geliştirmeyi tercih etti)

Tablo 6'da görüldüğü gibi kimya öğretmenleri analoji eğitimi öncesi ve sonrası toplam on üç analoji geliştirdi. Analiz çerçevesinde (bakınız Tablo 6) yer alan paylaşılan özelliklerin doğası kriterine göre bu analojilerden ikisi yapısal; on biri işlevsel özelliktedir. Temsil şekli kriterine göre bu analojilerden on üçü sözel özelliktedir. Soyutlama kriterine göre analojilerin on biri somut-soyut özelliktedir. Somut- somut ve soyut-soyut özellikte birer analoji bulunmaktadır. Eşleştirme derecesi kriterine göre biri zenginleştirilmiş, sekizi basit, dördü genişletilmiş özelliktedir. Yapaylık kriterine göre analojilerin tamamı günlük içerik özelliği taşımaktadır. Analoji teriminin kullanımı kriterine göre on üç analojinin dokuzunda analoji teriminin kullanılmadığı, dördünde kullanıldığı; sınırlılıkların tanımlanması kriterine göre analojilerin beşinde sinırlılıkların tanımlandığı, sekizinde tanımlanmadığı 
görülmektedir. Sistematiklik kriterine göre analojilerin sekizi yüksek; beşi düşük sistematik özelliktedir. Hedef ve analojinin alanlarına göre kriteriyle ilgili olarak Tablo 6'da sunulan bir analoji alan içindeki analoji özelliği göstermekte iken on iki analoji hedef ve analoğun farklı alanlardan seçildiği analoji özelliği göstermektedir.

\section{Sonuç ve Tartışma}

$\mathrm{Bu}$ araştırmanın birinci araştırma sorusu "kimya öğretmenlerinin öğretimlerinde analoji kullanımıyla ilgili hâlihazırdaki durumları ve geliştirdikleri analojilerinin nitelikleri nasıldır?" idi.

$\mathrm{Bu}$ araştırmaya katılan kimya öğretmenlerinin çoğunluğunun "analojiyi" "benzetme" olarak anlamlandırdığı bir kısmının "modelleme", bir kısmı ise "ilişkilendirme" olarak anlamlandırdığı tespit edildi. Derslerinde analojiyi kullanma sıklıkları "Kullanıorum" ve "Ara sıra kullanıorum" seçeneklerinde yoğunlaşmaktadır. Derslerinde kullanacakları analojiyi belirlerken en çok dikkat ettikleri husus "Günlük hayattan olması" şeklinde ortaya çıktı. Derslerinde analojileri sırasıyla "Anlamalarını sağlamak, kolaylaştırmak için", "Kalıcılığı sağlamak, Etkili öğrenmeyi sağlamak için" ve "Soyut konuları somutlaştırmak için" çoğunlukla kullandıkları belirlendi. Analojiler fen eğitiminde kavramları anlamlandırmayı kolaylaştıran, soyut kavramların somutlaştııılmasında etkili olan öğretim yöntemlerindendir (Dikmenli 2010; Dikmenli 2015, s.16; Dilber ve Düzgün, 2008, s.177). Derslerde analoji kullanıldığında öğrencilerin derse olan ilgileri artmakta, derse aktif katılım sağlanmakta ve öğrencilerin dikkat süreleri uzamaktadır (Harman ve Çökelez, 2017). Öğrenciler derse ve analojiye aktif katılım sağladıklarında öğrencilerde oluşabilecek kavram yanılgılarının önüne geçilebilmektedir (Thiele ve Treagust, 1991). Kullandıkları analojiler için başvurdukları kaynaklar sorulduğunda öğretmenlerin çoğu kaynak belirtmezken bir kısmı (üç kişi) “Doğaçlama olarak o anda aklıma gelen örnekler olabiliyor, kendim oluşturmaya çalışıyorum" şeklinde cevapladı. Derslerinde öğrencilerin analoji üretmelerine imkân tanıma durumlarıyla ilgili olarak beş öğretmen mümkün olduğunca öğrencilerine fırsat verdiğini belirtirken iki öğretmen ara sıra imkân tanıdığını belirtti. Analoji kullanımı öğrencilerde önceki bilgilerin hatırlanmasını, önceki bilgilerin kullanılmasını 
sağladığ1 ve kimya öğretiminde konulara günlük hayattan bakma şansı tanıdığı için kimya ders konularının öğrenilmesini kolaylaştıracaktır. Ayrıca öğrencilerde konuyla ilgili merak ve istek uyandıracaktır (Atav, Erdem, Yılmaz ve Gücüm, 2004, s.25; Glynn ve Takahashi, 1998, s.1129; Kobal, Şahin ve Kara, 2013, s.55; Rule, Baldwin ve Schell, 2008, s.1172).

Analoji kullanımının öğrenmeyi olumlu etkilediği (Atav vd., 2004, s.25; Çalık, Ayas ve Coll, 2009; Dikmenli 2010; 2015; Ekici vd., 2007), fen terimlerinin anlaşılmasını kolaylaştırdığı (Dikmenli 2010; 2015; Dilber, Düzgün, 2008), öğrenmeyi ve öğrenilen bilgi miktarını arttırdığı (Glynn ve Takahashi, 1998; Şaşmaz, Ören vd., 2010), analoji kullanımının konuyu kavramayı (Şenpolat, Seven ve Düzgün, 2005, s.97), kavramlar arasında ilişki kurmayı (Aykutlu ve Şen, 2012, s.281; Çalık vd., 2009, s.665), soyut ve anlaşılması zor kavramların anlaşılmasını kolaylaştırdığ (Dilber ve Düzgün, 2008, s.177) fen ve teknoloji derslerinde akademik başarıyı olumlu etkilediği (Kahraman Gökharman, 2013, s.53) çalışmalarla ortaya konulmuştur. Ayrıca analojilerin fen derslerindeki konuları günlük yaşamdaki olgu ve nesnelerle ilişkilendirmeye katkı sağladığ1 tespit edilmiştir (Şaşmaz, Ören vd. 2010, s.34).

Bu çalışmanın ikinci araştırma sorusu "Analoji eğitimi sonrası kimya öğretmenlerinin öğretimlerinde analoji kullanımıla ilgili görüşleri ve geliştirdikleri analojilerin nitelikleri nasıldır ?" şeklindeydi.

Eğitimden önce, analoji eğitimine katılmayı kabul eden dört kimya öğretmeninden üçü birer analoji geliştirirken bir öğretmenin (K4A1) geliştirdiği analoji örnek niteliğindeydi. Eğitim sonrası, öğretmenlerden birisi iki analoji geliştirmeyi tercih ettiği için toplam beş analoji geliştirmiş oldular. Eğitim öncesi, paylaşılan özelliklerin doğası kriterine göre, öğretmenlerin geliştirdikleri analojilerden biri (K1A1) yapısal özellikte iken; ikisi (K2A1, K3A1) işlevsel özellikte, birisi (K4A1) örnek niteliğindeydi. Eğitim sonrası katılımcı öğretmenlerin geliştirdikleri beş analojinin tamamı da işlevsel özellikteydi. Temsil şekli kriterine göre eğitim öncesi ve sonrası geliştirilen analojilerin tamamının sözel olduğu gözlendi. Ancak eğitim sonrası yapılan informal görüşmelerde katılımcı öğretmenler sözel/görsel analojilerin daha etkili olacağını belirterek, imkânları olduğu takdirde sözel/görsel analojileri kullanmayı tercih edeceklerini ifade ettiler. Soyutlama kriterine göre, eğitim öncesi geliştirilen analojilerden biri (K2A1) somut-somut, ikisi (K1A1, K3A1) somut-soyut 
iken; eğitim sonrası geliştirilen analojilerin tamamının somut-soyut özellikte olduğu gözlendi. Eşleştirme derecesi kriterine göre eğitim öncesi geliştirilen analojilerin tamamı (K1A1, K2A1, K3A1) basit özellikte iken; eğitim sonrası geliştirilen analojilerden biri (K4A2) zenginleştirilmiş, dördü ise (K1A2, K2A2, K2A3, K3A2) genişletilmiş özellikteydi. Yapaylık kriterine göre ise eğitim öncesi geliştirilen üç analoji ve eğitim sonrası geliştirilen beş analoji de günlük içerik özelliği taşımaktaydı. Analoji teriminin kullanımı kriterine göre ise eğitim öncesi geliştirilen analojilerde analoji teriminin kullanılmadığı; eğitim sonrası geliştirilen analojilerin ikisinde (K2A2, K2A3) analoji teriminin kullanıldığ1, üçünde (K1A2, K3A2, K4A2) kullanılmadığ1 gözlendi. Sistematik olarak kriterine göre eğitim öncesi geliştirilen analojilerden sadece biri (K2A1) yüksek diğer ikisi (K1A1, K3A1) düşük sistematik özellikte iken; eğitim sonrası geliştirilen beş analoji de yüksek sistematik özellikteydi. Sınırlılıkların tanımlanması kriterine göre eğitim öncesi geliştirilen analojilerin üçünde de sinırlılıklar tanımlanmazken; eğitim sonrası geliştirilen analojilerin tamamında da sinırlılıkların tanımlandığı gözlendi. Eğitim öncesi geliştirilen analojilerin tamamı alanlar arası analoji iken, eğitim sonrası geliştirilen analojilerden bir tanesinin (K2A2) alan içi analoji, dört tanesinin ise alanlar arası analoji olduğu gözlendi. Harman ve Çökelez'in (2017) de vurguladığı gibi günlük yaşamdan faydalanılarak öğrenilecek kavramlara ilişkin analojik ilişkiler kurabilen bireyler çevrelerini daha dikkatli bir şekilde gözlemleyerek, etraflarında olan olaylara daha bilinçli yaklaşarak, olaylara sadece bakmakla kalmayıp olayları görmeye de başlayabilirler (Harman ve Çökelez, 2017). Bu çalışmada eğitim sonrasında K2 kodlu katılımcı tarafından geliştirilen alan içi analojinin (K2A2) "Kimya ve Elektrot" konusundaki "Standart Elektrot Potansiyellerinin Belirlenmesi" konusu ile ilgili bir analoji olduğunu ve bu analojide katılımcinın hedef kavram olarak "Standart elektrot potansiyeli" ni analog kavram olarak da "Termometre" yi belirlediğini ve analog kavramla ilgili olarak da termometrenin yapılışında esas alınan varsayımlara odaklandığını görüyoruz. Öğretimde daha önce öğrenilen kimya konu, kavram, ilke veya prensiplerinin analog kavram olarak seçilip hedef kavramın bunun üzerinden kavratılmaya çalışılması şeklinde alan içi analojilerin kullanılması, önceki bilgilerin hatırlanması, pekiştirilmesi yeni öğrenilen bilgilerin önceki bilgilerle ilişkilendirilmesi 
gibi birçok açıdan avantajlı olabilir ancak bu noktada öğrencilerin analog kavram olarak atanan önceki bilgilerinde hatalı, eksik veya yanlış kavramaların olmamasına dikkat edilmesi gerekir aksi takdirde öğrencilerin analog kavramla ilgili taşıdıkları hatalı, eksik veya yanlış kavramalar domino etkisiyle hedef kavrama sirayet edebilir.

Analoji eğitimi sonrası kimya öğretmenlerinin analoji eğitiminde edindikleri bilgi ve becerileri derslerine enteğre etmeyle ilgili görüşlerine baktığımızda dört katılımcının da olumlu görüş bildirdiği görülmektedir. Olumlu görüşlerin detaylarını daha iyi sunabilmek için aşağıda katılımcların görüşlerinden doğrudan alıntılara yer verildi.

"Kesinlikle evet. Bilmeden zaten kullanıyormuşum. Ama şu andan sonra daha bilinçli bir şekilde uygulayacağım." (K1)

"Kesinlikle. Analojiyi zaten kullandığımı ama sistematiğini bilmediğimi fark ettim." (K2)

"Evet. Burada öğrendiğim bilgi ve becerileri ders işlerken kullanmayı ve planlama yaparken bunları dikkate almayı düşünüyorum. Öğrencilerin öğrenmekte zorlandığı konu ve kavramları bu yöntemle daha kolay öğretebileceğimi düşünüyorum.

İlave bir bulgu olarak, eğitimden sonra eğitime katılan kimya öğretmenleriyle yapılan informal görüşmelerde, öğretim deneyimleriyle ilgili olarak yaptıkları yansıtmalarda öğretmenler, öğrencilerden bazılarının analojinin içinde kaldığını, sınavlarda analoji kullanarak öğrettikleri kavramla ilgili soru sorduklarında öğrencilerden bazılarının hedef kavram yerine analojiyi açıkladıklarını belirterek bu durumla başetmek için bu araştırma kapsamında öğrendikleri “Analoji ile Öğretim” modelinin sunduğu aşamalı, sistematik yapıyı kullanmanın çok etkili olacağını ifade ettiler.

$\mathrm{Bu}$ çalışmanın kimya öğretmenlerinin aldıkları analoji eğitimi sonrasında geliştirdikleri analojilerin niteliğinin yükselmesi ve öğretmenlerin öğretimde analoji kullanımı ile ilgili bakış açılarının ve görüşlerinin gelişip, güçlendiğini ortaya koyan bulguları, Harman ve Çökelez'in (2017) öğretmen, öğretmen adayı ve öğrenciler analoji oluşturma ve kullanma ile ilgili aldıkları eğitimin ardından analojiler oluşturmalıdır şeklindeki önerilerini destekler niteliktedir. 


\section{Öneriler}

Kimya öğretmenlerine yönelik öneriler; $\mathrm{Bu}$ çalışmada elde edilen bulgulara dayalı olarak kimya öğretmenlerine analoji, öğretimde analojilerin nasıl kullanılması gerektiği, öğretimde analoji kullanımının sağlayacağı avantajlar ve bu bilgilerin sınıf içi pratiklerine sistematik bir biçimde nasıl yansıtılacağı ile ilgili iyi uygulama örneklerini de içeren hizmet içi eğitimlerin verilmesi ve bu eğitimlere alan bilgisi ve pedagojik alan bilgisi iyi olan eğitimciler tarafından hazırlanmış güçlü analojilerin dâhil edilmesinin, bu eğitimlerde ders kitaplarındaki analojilerin bazı ölçütlere göre analiz edilmesinin ve öğretmenlerin analoji içeren materyaller üretmelerine imkân tanınmasının öğretmenlerin gelişimine somut katkılar sağlayacağı düşünülmektedir.

Kimya öğretmenlerine kimya ders kitaplarında yer alan analojileri öğrencilere doğrudan aktarmak yerine analojileri bilgi süzgecinden geçirerek analojideki kaynak ve hedef kavramını belirleyip, paylaşılan ve paylaşılmayan özellikleri ortaya koyup görsellerle destekleyerek başka bir ifadeyle ders kitaplarındaki analojileri geliştirip, güçlendirerek kullanmaları önerilebilir.

Kimya eğitimi araştırmacılarına yönelik öneriler; Kimya eğitimcilerine ise kimya öğretiminde analoji kullanımıyla ilgili olarak kimya öğretmenleriyle gerçekleştirecekleri çalışmalarda daha çok kimya öğretmenine ulaşmayı hedeflemeleri önerilebilir. 


\title{
EXTENDED ABSTRACT
}

\section{Examination of the Use of Analogy in the Teaching of Chemistry Teachers}

\author{
Ayşegül Derman- Mehmet Tufan \\ Necmettin Erbakan Univesity
}

The present qualitative study, which was carried out in the spring semester of the 2018-2019 academic year, focused on determining the current situation of chemistry teachers regarding the use of analogies, the qualities of the analogies they use and improving them.

This research is a case study. The study was carried out with twelve chemistry teachers. After determining the current use of analogies of twelve chemistry teachers and the qualifications of the analogies they use, four chemistry teachers who agreed to participate in the training were given analogy training, and it was aimed to improve the competencies of the teachers about the use of analogies in chemistry teaching after the training.

The data source of the current research was the written answers given by the chemistry teachers to open-ended questions before and after the analogy training.

Content analysis technique was used to analyze the data in the present study.

In the present research we reached the findings in the following categories; how chemistry teachers make sense of "Analogies", "frequency of use of analogies in their lessons", "the points they pay attention to when determining the analogies to be used in their lessons", "the purpose of using analogies in their lessons", "the resources they refer to for the analogies they use", "the situation of allowing students to produce analogies in their lessons". Six categories emerged regarding the use of analogies in the teaching of chemistry teachers. The vast majority of the participants explained the analogy with the answer "simile". The most dominant codes that emerged regarding the frequency of analogy use in chemistry teachers' classes are "I use" and "I use it occasionally" codes. The issues that chemistry teachers consider most when determining 
analogies are respectively "being from daily life", "subjects, concepts, appropriateness for acquisitions", "level of students, compatibility with interest level". The three most prominent codes that emerged regarding the purpose of using analogies in chemistry teachers' lessons are respectively "To make them understand, to facilitate", "To ensure persistence, to ensure effective learning", "To concretize abstract topics". Most of the chemistry teachers did not specify the sources they used for the analogies they used in the lessons, three of them answered, "I can come up with examples that come to mind at that moment as improvisation, I try to create my own". As far as possible, five of the chemistry teachers related to the situation of allowing students to produce analogies in their classes; two of them stated that they occasionally give their students an opportunity. The findings also revealed that the chemistry teachers who participated in the analogy training had a great deal of improvement in their knowledge and opinions about the structure of pedagogical analogous models, their properties, how to use them in teaching, and the points to be considered when using analogies in teaching. It was observed that all four participants gave positive opinions about integrating the knowledge and skills acquired in the analogy training of chemistry teachers into their lessons. Before the training, three of the four chemistry teachers who agreed to participate in the analogy training developed an analogy, while the analogy developed by one teacher was exemplary. After the training, because one of the teachers preferred to develop two analogies, they developed a total of five analogies. According to the criterion of the nature of shared characteristics before the education, one of the analogies developed by the teachers was structural; Two of them were functional and one was exemplary. All five analogies developed by the participating teachers after the training were functional.

It was observed that all of the analogies developed before and after the training according to the representation criteria were verbal. However, in the informal interviews held after the training, the participating teachers stated that verbal/visual analogies would be more effective and they would prefer to use verbal/visual analogies if they had the opportunity. According to the abstraction criterion, one of the analogies developed before the education is concrete-concrete, while the other two are concrete-abstract; It was observed that all of the analogies developed 
after the training were of concrete-abstract nature. While all of the analogies developed before the training according to the matching degree criterion were simple; one of the analogies developed after the training was enriched and four were extended. According to the artificiality criterion, three analogies developed before the training and five analogies developed after the training had the characteristics of daily content. According to the criterion of the use of the term analogy, it is stated that the term analogy is not used in the analogies developed before the training; It was observed that the term analogy was used in two of the analogies developed after the training and it was not used in three. While only one of the analogies developed systematically before the training was high and the other two were of low systematic feature; All five analogies developed after the training were of high systematic character. According to the criteria of defining the limitations, limitations were not defined in all three of the analogies developed before the training; It was observed that limitations were defined in all of the analogies developed after the training. While all of the analogies developed before the training were inter-field analogies, it was observed that one of the analogies developed after the training was intra-field analogy and four of them were interfield analogies.

After the training we also reached some additional findings via the informal interviews with the chemistry teachers who attended the training, they made some reflections about their previous teaching experiences, the teachers stated that some of the students remained in the analogy, and when they asked questions in the exams about the concept they taught by using analogy, some of the students explained the analogy instead of the target concept. They stated that it would be very effective to use the gradual and systematic structure offered by the "Teaching by Analogy" model that they learned in analogy training within the scope of the present research. 


\section{Kaynakça/References}

Adnan, Y. Z. (2015). Ortaöğretim 12. Sinıf biyoloji ders kitaplarında kullanulan analojiler üzerine bir araştırma. Yüksek Lisans tezi. Necmettin Erbakan Üniversitesi Eğitim Bilimleri Enstitüsü, Konya.

Atav, E., Erdem, E., Yllmaz, A. ve Gücüm, B. (2004). Enzimler konusunun anlamlı ögrrenilmesinde analojiler oluşturmanın etkisi. Hacettepe Üniversitesi Ĕ̆itim Fakültesi Dergisi, 27, 21-29.

Ayas, A., ve Sözbilir, M. (2017). Kimya öğretimi: Öğretmen eğitimcileri, öğretmenler ve öğretmen adayları için iyi uygulama örnekleri. Pegem Atıf İndeksi, 1-810.

Aykutlu, I. ve Şen, A. İ. (2012). Üç aşamalı test, kavram haritası ve analoji kullanılarak lise öğrencilerinin elektrik akımı konusundaki kavram yanılg1larının belirlenmesi. Eğitim ve Bilim, 37(166), 275-288.

Azizoğlu, N., Aslan, S., ve Pekcan, S. (2015). Periyodik Sistem konusu ve analojilerle öğretim modeli: Yöntem, Cinsiyet ve motivasyon faktörlerinin öğrenci başarısına etkisi. Ilköğretim Online, 14(2), 472-488.

Berg, B. L., ve Lune, H. (2015). Sosyal bilimlerde nitel araştırma yöntemleri. Konya: Eğitim Yayınevi.

Büyüköztürk, Ş., Kılıç Çakmak, E., Akgün, Ö. E., Karadeniz, Ş., ve Demirel, F. (2016). Bilimsel araştırma yöntemleri (23. Baskı). Ankara: Pegem Akademi.

Cha, J., Byun, S., ve Noh, T. (2004). The analysis of analogies in chemistry content of secondary school science textbooks based on the 7th national curriculum. Journal of The Korean Chemical Society, 48(6), 629-637.

Creswell, J. W. (2016a). Research design: Qualitative, quantitative, and mixed methods approaches. (S.B. Demir, Çev. Ed.). Ankara: Eğiten Kitap Yayınları.

Creswell, J.W. (2016b). Qualitative inquiry and research design: Choosing among five approaches. (M. Bütün ve S.B. Demir, Çev.Ed.). Ankara: Siyasal Kitabevi.

Çalık, M., Ayas, A., ve Coll, R. K. (2009). Investigating the effectiveness of an analogy activity in improving students' conceptual change for solution chemistry concepts. International Journal Of Science And Mathematics Education, 7(4), 651-676.

Çimen, S. V., ve Baran, G. (2000). Fen kavramlarının öğretiminde analojinin kullanımı ve öğretmen rolü. II. Ulusal Öğretmen Yetiştirme Sempozyumu, Çanakkale, Çanakkale Onsekiz Mart Üniversitesi, Eğitim Fakültesi.

Dagher, Z. R. (2005). The case for analogies in teaching science for understanding. In Teaching science for understanding (p.195-211). Academic Press. 
Damarer, E. (2006). Fizik, kimya ve biyoloji ögrretmenleri tarafindan kullanılan analojilerin analizi. Yüksek Lisans Tezi. Gazi Üniversitesi, Eğitim Bilimleri Enstitüsü, Ankara.

Dikmenli, M. (2010). An analysis of analogies used in secondary biology textbooks: Case of Turkey. Eurosian Journal of Educational research, 41, 73-90.

Dikmenli, M. (2015). A study on analogies used in new ninth grade bilogy textbook. Asia-Pasific Forum On Science Learning And Teaching, 16(1), 120.

Dilber, R., ve Düzgün, B. (2008). Effectiveness of analogy on students' success and elimination of misconception. Latin-American Journal Of Physics Education, 2(3), 174-183.

Duit, R. (1991). On the role of analogies and metaphors in learning science. Science education, 75(6), 649-672.

Ekici, E., Ekici, F., ve Aydın, F. (2007). Fen bilgisi derslerinde benzeşimlerin (analoji) kullanılabilirliğine ilişkin öğretmen adaylarının görüşleri ve örnekleri. Ahi Evran Üniversitesi Kirşehir Eğitim Fakültesi Dergisi (KEFAD), 8(1), 95-113.

Glynn, S. M. (1989). The teaching with analogies model: Explaining concepts in expository texts. In K. D. Muth (ed.), Children's comprehension of narrative and expository text: Research into practice (p.185-204). Newark: International Reading Association.

Glynn, S. M., ve Takahashi, T. (1998). Learning fron analogy-enhanced science text. Journal of Research in Science Teaching, 35(10), 1129-1149.

Harman, G., ve Çökelez, A. (2017). Analojilerin fen eğitimindeki yeri ve önemi. Necatibey Eğitim Fakültesi Elektronik Fen ve Matematik Eğitimi Dergisi (EFMED) 11(1), 340-363.

Harrison, G. A., ve Treagust, F. D. (2000). A typology of science models. International Journal of Science Education, 22(9), 1011-1026.

Kahraman Gökharman, H. (2013). Maddenin Yapısı ve Özellikleri ünitesinde analoji kullanımınin öğrenci başarısı ve tutumuna etkisi. Yüksek Lisans Tezi. Pamukkale Üniversitesi Eğitim Bilimleri Enstitüsü, Denizli.

Kesercioğlu, T., Yılmaz, H., Huyugüzel Çavas, P., ve Çavas, B. (2004). İlköğretim fen bilgisi öğretiminde analojilerin kullanımı: Örnek Uygulamalar. Ege Eğitim Dergisi, 5(1), 44.

Kobal, S., Şahin, A., ve Kara, İ. (2013). Fen ve teknoloji dersinde analojilere dayalı öğretimin öğrencilerin başarıları ve hatırda tutma düzeyi üzerindeki etkisi. Buca Ĕ̆itim Fakültesi Dergisi, 36, 46-61. 
MEB- Milli Eğitim Bakanlığ1- (2018). Ortaöğretim kimya dersi öğretim programi. http://mufredat.meb.gov.tr/ProgramDetay.aspx?PID=350. 31.05.2019

Moğol, S., Bağı, N., ve Günçiçek, Ç. (2003). Öğrencilerin atom yapısı-güneş sistemi pedagojik benzeştirme (analoji) modelini analiz yeterlilikleri. Mili Eğitim Dergisi, 159, 74-84.

Rule, A. C., Baldwin, S., ve Schell, R. (2008). Second graders learn animal adaptations through form and function analogy object boxes. International Journal of Science Education, 30(9), 1159-1182.

Saka, A. Z. (2004). Fen öğretiminde kullanılan somutlaştırma araçları ve uygulama düzeyleri. IV. Ulusal Fen Bilimleri ve Matematik Eğitimi Kongresi, İstanbul, 1, 245.

Serin Ergin, Ö. (2009). Öğrenci ve öğretmenlerin 11. smmf kimya konular ile ilişkili analojilerdeki benzerlik ve farklllkkları belirleme düzeyleri. Yüksek Lisans Tezi. Balıkesir Üniversitesi, Fen Bilimleri Enstitüsü, Balıkesir.

Şaşmaz-Ören, F., Ormancı, Ü., Babacan, T., Çiçek, T., ve Koparan, S. (2010). Analoji ve araştırma temelli öğrenme yaklaşımına dayalı rehber materyal uygulaması ile buna yönelik öğrenci görüşleri. Batı Anadolu Eğitim Bilimleri Dergisi, 1(1), 33-53.

Şenpolat, Y., Seven, S., ve Düzgün, B. (2005). Fen bilgisi öğretiminde analoji kullanımının öğrenci başarısına ve derse yönelik tutumlarına etkisinin araştırılması. Çukurova Üniversitesi Ĕ̆itim Fakültesi Dergisi, 31(2), 94-101.

Taber, K. S. (2008). Towards a curricular model of the nature of science. Sci $\mathcal{E}$ Educ, 17, 179-218.

Thiele, R. B., ve Treagust, D. F. (1991). Using analogies to aid understanding in secondery chemistry education. Royal Australian Chemistry Conference On Chemical Education, Perth, Western Australia.

Thiele, R.B., ve Treagust, D. F. (1995). Analogies in chemistry textbooks. International Journal Of Science Education, 17,783.

\section{Kaynakça Bilgisi/Citation Information}

Derman, A. ve Tufan, M. (2021). Kimya öğretmenlerinin öğretimlerinde analoji kullanım durumlarının incelenmesi. OPUS- Uluslararası Toplum Araştırmaları Dergisi, 18(44), 7749-7776. DOI:10.26466//opus.957650. 